The Calling ...

\title{
THE CALLING OF PARADISE ON EARTH: MARKETING MIX FACTORS ANALYSIS FOR FOREIGN TOURISTS IN BALI
}

\author{
I Dewa Made Agung Kertha Nugraha \\ Paulina
}

\begin{abstract}
Purpose - For the past decade, cultural resources and tourism have become inextricably linked throughout the world especially in developing countries. This study aims at determining the factors of Bali tourism marketing mix priority for foreign tourist. Design/methodology/approach - The research applied quantitative method and employed an Analytical Hierarchy Process (AHP) for examining the dominant factors based on data collected from97 foreign tourists who fulfilled the questionnaires.

Findings - The findings of the study reveal that marketing mix factors that has the highest value from foreign tourist about Bali tourism is the price factor with a weight of 0.200 followed by product factor $(0,160)$, promotion factor $(0,159)$, people $(0,134)$, physical evidence $(0,123)$, process $(0,166)$, and the last position is place factor which has a weight of $(0,107)$.
\end{abstract} Keywords: marketing mix, tourism, tourist, factor analysis, analytical hierarchy process.

\section{INTRODUCTION}

\subsection{Background}

Tourism is one of several sectors that are used as a backbone by the government in obtaining foreign exchange from non-oil and gas income. Tourism is not only a source of foreign exchange incomes in national development but also contributes to creating jobs, increasing the income of the people and the government, enhancing the preservation of the environment and national culture, tightening and strengthening national unity.

Competition in the tourism sector has been quite intense in the Southeast Asia region, given the implementation of the ASEAN Free Trade Area (AFTA) for countries such as Brunei Darussalam, Indonesia, the Philippines, Singapore, Malaysia, and Thailand. The competition between ASEAN countries is quite fierce, considering the countries in the region are relatively selling similar attractions because of the similarity of clumps, historical roots, traces of culture and civilization, and natural conditions.

However, unfortunately, the average tourist arrivals to Indonesia are always losing compared to Malaysia, Thailand, and Singapore. Indonesia only has more foreign tourist visits than Brunei Darussalam and the Philippines, which since 2002 have implemented AFTA. While Cambodia, Laos, and Vietnam will only implement AFTA in full in 2015 and Myanmar by 2020 has grown into a new competitor.

For Indonesian tourism itself, especially Bali, it is a tourist destination that is crowded with domestic and international tourists. Seen in terms of tourism objects, Bali has advantages compared to other islands. No wonder if then Bali became the mainstay island for Indonesia in terms of tourism. Lately, an international Travel magazine released 10 of the most beautiful islands in Asia for the 2012 version of its readers. In the ten islands, Bali ranks first. At least seven criteria form the basis of the assessment of the best island in Asia in 2012.

For Bali's tourism conditions, Bali currently occupies the top position in the ranking of world tourism destinations, but with the high position of Bali Island in international tourism competition, it has become a good and dangerous moment for Bali. It is said to be dangerous 
because if Bali does not continue to improve and change in a better direction through innovation and creativity in terms of tourism, or other words remain in the status quo, competitors will continue to compete with Bali.

Change management is needed for the island of Bali. The high position of Bali in tourism competition is a perfect moment to make changes. According to (Sigmund, 2011) in the strategy of making changes, the best condition of a company or organization to make changes, and innovation is when the company is in a top position.

Based on the phenomena described above, the researcher tried to examine the marketing mix factors as a priority for foreign tourists regarding tourism in Bali. The purpose of this study was to determine whether the marketing mix factors were a priority for foreign tourists regarding Bali's tourism.

\section{THEORETICAL BASIS}

\subsection{Literature review}

\subsubsection{Tourism}

According to Yoeti (1980), what is meant by tourism is a journey that is carried out temporarily, which is held from one place to another which is intended not to try or make a living in the place he is going to visit, but solely to enjoy the journey in order to sightseeing and recreation or fulfilling diverse desires. Moreover, what is meant by tourism according to Law No. 10/2009 on Tourism, tourism is a variety of tourism activities supported by various facilities and services provided by the community, entrepreneurs, the Government, and the Regional Government.

\subsubsection{Types of Tourism}

According to Spillane (1994), the types of tourism based on destination and travel motivation are grouped into:
1. Pleasure tourism
2. Recreation tourism
3. Culture tourism
4. Sports tourism
5. Business tourism
6. Convention tourism

\subsubsection{Marketing}

Marketing is a process carried out by each company to create value for customers and build strong relationships with the customers themselves and get value from customers in return (Kotler \& Armstrong, 2012). Whereas According to the American Marketing Association (AMA) cited Kotler and Keller (2007) marketing is an organizational function and a set of processes for creating, communicating, and delivering value to customers and managing customer relationships in ways that benefit the organization and its shareholders.

\subsubsection{Marketing Concept}

Understanding the concept of marketing is the philosophy of marketing management to achieve organizational goals depending on determining the needs and desires of the target market and satisfying customers more effectively and efficiently than those of competitors (Kotler and Armstrong, 2012). There are four things which are the main elements Marketing concepts are (Kotler and Armstrong, 2012):

1. Market focus

2. Orientation to customers

3. Integrated marketing

4. Profit through customer satisfaction 
The Calling ...

It can be concluded that with the marketing concept, companies explore what consumers want and need and then develop products that will satisfy consumers' desires while earning profits. However, along with the development of technology and society, it has led to the development of marketing concepts as well.

\subsubsection{Tourism Marketing}

Krippendorff in his book Marketing et Tourism gives the definition of tourism marketing (Wahab, 1997) as follows: "Systematic adjustment and coordination of policies of tourism business entities and policies in the tourism sector at the government, local, regional and international levels to achieve an optimal satisfaction point for particular customer group needs that have been previously set, as well as to make an adequate level of profit"

The interaction between products and the tourist market is essential so that tourist markets can obtain information about the products offered so that the needs of tourists can be met. Another limitation of tourism marketing then arises, as an improvement in the previous limits. These limits (Wahab, 1997) are as follows: "The management process by which tourism organizations or tourism agencies can identify their chosen tourism, both actual and potential, can communicate with them to convince and influence the will, needs, motivations, preferences and things that are not favored at the local, regional, and formulate and adjust their tourism products appropriately, with a view to achieving optimal tourist satisfaction, so that they can achieve their goals."

\subsubsection{Buying decision}

According to Shciffman and Kanuk (2010), the decision is a selection of two or more alternative options. Whereas according to Kotler and Armstrong (2012) suggest that: "purchasing decisions are decisions of consumers where consumers purchase products.

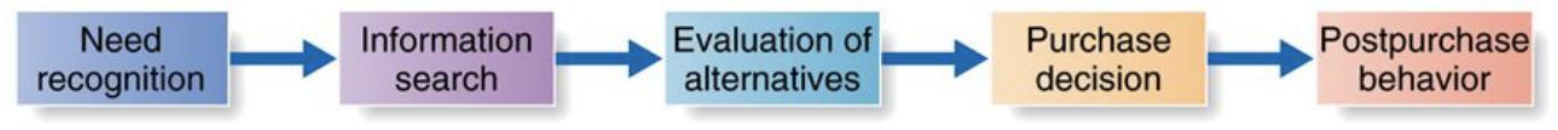

Figure 2.1. The Buyer Decision Process (Kotler, Armstrong, 2012)

\subsubsection{Promotion}

Promotion is one of the variables in the marketing mix that is very important in marketing service products. The concept used to introduce the product is the promotion mix. Promotion mix is an activity that is very important to be implemented in product marketers. Through this promotional mix activity, the company strives to notify consumers. About a product and encourage to buy the product. Many ways are done by companies to promote their products, including:

1. Personal Selling

2. Advertising

3. Public Relations

\subsubsection{People}

According to (Zeithaml, 2009) what is meant by people is all the factors of people who play a part in the distribution of services and thus the influence of consumer perceptions namely, personal companies, customers, and customers in the service environment. People are one of the marketing mix elements. Society here is defined as service. About service 
marketing, the "people" functioning like service providers greatly influence the quality of services provided.

The importance of "people" in marketing services is closely related to internal marketing. Internal marketing (Lupiyoadi and Hamdani, 2008) is the interaction or relationship between each employee and department in a company, which in this case can be positioned as internal consumers and internal suppliers. The purpose of the relationship is to encourage "people" in performance to give satisfaction to consumers.

\subsubsection{Process}

The process is defined as actual procedures, mechanisms, and the flow of activity through something where services are delivered, service delivery, and operating systems (Zeithaml et al., 2009). The characteristics of the process factors offered to consumers are whether the service product approach is standardized or customized. Standardized is the process by which these services cannot be enjoyed by the wishes of personal consumers, but are standardized, i.e., they cannot be changed according to individual preferences. While what is meant by customized is the process by which these services can be enjoyed and consumed by the wishes of personal consumers. For example, two well-known airlines, Southwest and Singapore Airlines, have different process models. Southwest is a no-frills airline (no food available), an affordable airline that generally serves short-haul flights. All forms of services are consistent and by the market position. While Singapore Airlines, on the other hand, focuses on business travel and concern with traveller needs meetings, therefore the service process can be adjusted according to their individual needs. Both airlines are successful airlines despite having a different service process approach.

What needs to be underlined here is that the characteristics of this process are not seen from what is better or not, but about consumer preferences to choose which service process they want.

\subsubsection{Physical Evidence}

Sarker et al. (2012) explained that physical evidence could easily be associated with products by tourists. However, in this case, the physical evidence is also interpreted as a supporting factor to get the service product.

According to Zeithaml, et al., (2009) what is meant by physical evidence is the environment in which a service is delivered and where the company and customers interact, and some tangible components that facilitate the communication performance of the service.

Whereas according to Lupiyoadi and Hamdani (2008), physical evidence is the physical environment of the company where services are created and where service providers and consumers interact, plus any tangible elements used to communicate or support the role of the service. Also, it can be used to support positioning and image and increase product scope.'

\section{RESEARCH METHODOLOGY}

\subsection{Object of research}

This research took place on the island of Bali. There are many tourist attractions, natural beauty, high cultural, religious and moral values that are still held firmly by the people of Bali and make Bali Island a tourist destination that is endlessly visited by foreign tourists.

\subsection{Research design}

In this study, researchers chose the type of exploratory research. Explorative research is research that is conducted to explore extensively about the causes or things that influence the occurrence of something. 
The Calling ...

\subsection{Research time}

The author conducted this research in the Province of Bali, and this research was conducted from April to June 2013.

\subsection{Population and sample}

\subsubsection{Population}

The population of this study was foreign nationals who were and had visited Bali.

\subsubsection{Sample}

The researcher distributed questionnaires to foreign nationals who had been on vacation in Bali, namely in Denpasar, Tabanan, Gianyar, Badung, including Spiritual Tourism, Temple, Lake, Ecotourism, Art and Culture, Art Villages, Historical Building, Shopping, Water Sport and Adventure. This research is estimated to take around two weeks to get 97 foreign respondents on the island of Bali.

\subsection{Data collection technique}

\subsubsection{Sampling technique}

Because the population is infinite, in this study, the sampling technique used is accidental sampling, which is the technique of determining samples of people or objects based on coincidences encountered.

\subsubsection{Determination Technique of Sample Amount}

Given the exact number of population unknown, the determination of the number of samples to be used in this study uses a formula from Rao Purba (1996) in Purnamasari (2011), namely as follows:

$$
n=\frac{\mathrm{Z}^{2}}{4(m o e)^{2}} \quad n=\frac{1,96^{2}}{4(0,1)^{2}} \quad n=96,04
$$

Information

$\mathrm{n}=$ Number of Samples

$Z=$ The level of confidence needed in the study $(95 \%=1,96)$

Moe $=$ Margin of error (a maximum error that can be tolerated is $10 \%$ )

Based on the formula above can be taken samples from a population of 96.04 people, but because there are elements of rounding and to facilitate the calculation, the researcher took a sample of 96 respondents.

\subsection{Data Processing Techniques}

\subsubsection{Qualitative Data Processing Techniques}

Qualitative data analysis is a form of study based on data stated in the form of description. This qualitative data is data that can only be measured directly (Hadi, 2001). This qualitative analysis process is carried out in the following stages:

\section{Editing}

Editing is choosing or retrieving data that is necessary and discarding data that is deemed unnecessary, to facilitate calculations in testing hypotheses.

Coding

The process of giving specific codes to types from questionnaires to groups into the same category. 
Scoring

Change qualitative data into the quantitative form. In this study, the order of scoring uses a current scale.

Tabulating

Grouping the data on the answers correctly and carefully, then counted and added up until tangible in a useful form. Based on the results of the table, it will be agreed to make table data to get a relationship or influence between the variables.

\subsubsection{Quantitative Data Processing Techniques}

To get quantitative data, Saati scale is used which is obtained from setting the priority of elements in a decision problem is to make paired protection (pairwise comparison), each item compared to pairing with a specified criterion.

The Saati Scale explains the values 1 - 9 that are set for consideration in comparing pairs of similar elements at each level of the hierarchy against a criterion that is level above it. Experience has proven that a scale with nine units is acceptable and reflects the degree to which it can distinguish the intensity of the relationship between elements. Saati scale can be seen in the following table.

\begin{tabular}{|c|c|c|}
\hline $\begin{array}{l}\text { Level of } \\
\text { Interest }\end{array}$ & $\begin{array}{c}\text { Definitio } \\
n\end{array}$ & Description \\
\hline Value 1 & Equal impotance & $\begin{array}{l}\text { Two elements have the } \\
\text { same effect on the goal }\end{array}$ \\
\hline Value 3 & Slightly more importance & $\begin{array}{l}\text { Experience and judgment } \\
\text { support a single element } \\
\text { rather than another element }\end{array}$ \\
\hline Value 5 & Materially more importance & $\begin{array}{l}\text { Experience and assessment } \\
\text { are very strong in supporting } \\
\text { an element compared to } \\
\text { other elements }\end{array}$ \\
\hline Value 7 & Significantly more importance & $\begin{array}{l}\text { One element is strongly } \\
\text { supported and dominantly } \\
\text { involved in nractice }\end{array}$ \\
\hline Value 9 & Absolutely more importance & $\begin{array}{l}\text { Evidence that supports one } \\
\text { element against another has } \\
\text { the highest degree of } \\
\text { affirmation that might }\end{array}$ \\
\hline Value $2,4,6,8$ & Compromise values & $\begin{array}{l}\text { This value is given if there are } \\
\text { two compromises between }\end{array}$ \\
\hline $\begin{array}{c}\text { Reversed } \\
\text { Value }\end{array}$ & $\begin{array}{c}\text { If for activity I get number } 2 \\
\text { when compared to activity } \mathrm{j} \text {, } \\
\text { then it has a value of } 1 / 2 \\
\text { compared to } \mathrm{i}\end{array}$ & \\
\hline
\end{tabular}

Source: Saati 
The Calling ...

\subsection{Testing Techniques}

\subsubsection{Consistency Test and Ratio}

One of the advantages of the AHP model that distinguishes it from other decisionmaking models is that there is no absolute consistency requirement. With the AHP model that uses the perception of the decision-maker as its input, inconsistency may occur because humans have limitations in expressing their perceptions consistently, especially when they have to compare many criteria. Based on this condition, the decision-maker can express his perception freely without having to think whether his perception will be consistent or not.

Measurement of the consistency of a matrix itself is based on the maximum eigenvalue. Thomas $\mathrm{L}$. Saati has proved that the following formula can obtain the consistency index of a matrix with a number.

$\mathrm{Cl}$ : consistency (inconsistency index) ratio

$\lambda$ : The largest eigenvalue of the matrix has the order $n$

$\mathrm{N}$ : Order matrix

$$
C I=\frac{(\lambda \max -n)}{(n-1)}
$$

If $\mathrm{Cl}$ is zero, then the pairwise comparison matrix is consistent. The inconsistency limit set by Thomas L. Saati is determined by using the Consistency Ratio (CR). That is the comparison of index consistency. The random index value $(\mathrm{Rl})$ obtained from an experiment by Oak Ridge National Laboratory was then developed by the Wharton School and shown as table 3.1. This value depends on the order of matrix 11. Thus the Consistency Ratio can be formulated as follows:

If the pair-wise comparison matrix with a CR value is smaller than 100 , then the inconsistency of opinion from the decision-maker is still acceptable, if not, then the assessment needs to be repeated.

\subsubsection{AHP Analysis}

Analytical Hierarchy Process (AHP) is a research method for decision making in complex, unstructured situations, into more structured parts, starting from goals, objectives, then sub-objectives and then becoming alternative actions. Decision-makers then make a simple comparison of the hierarchy to get the priority of all available alternatives.

The following are the steps that must be taken in this study to process data using the AHP Method:

1. Determining goals based on the background of existing problems, the purpose taken is to analyze the priority factors of Bali Island's tourism marketing mix for foreign tourists on vacation on the island of Bali.

2. Determine criteria, criteria obtained from the results of previous research, and related theory books.

3. Determine alternatives. This alternative is also obtained from the results of previous research and related theory books.

4. Disseminate questionnaires to respondents (key-person) who experienced direct tourism in Bali, in this case, foreign tourists who are on vacation or have vacationed on the island of Bali. These criteria and alternatives can be arranged hierarchically as follows 


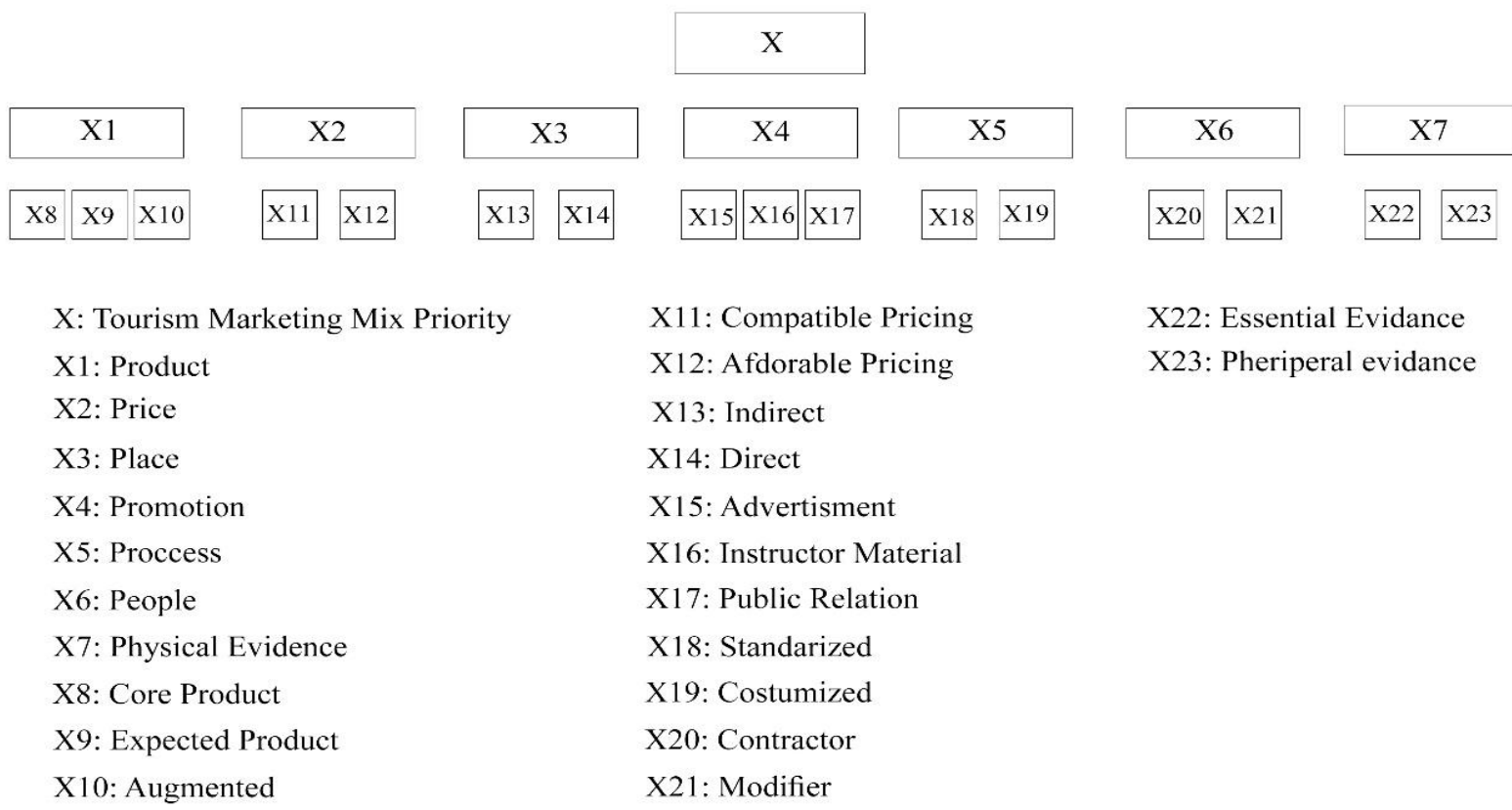

5. Compile a matrix of the average results obtained from key-person respondents in this study. Then the results are processed using the Expert Choice application 11.

6. Analyze the processing of Expert Choice Version 11 to find out the results of inconsistency and priority values. If the consistency value is more than 0.10 , then the results are inconsistent, but if the value is less than 0.10 , then the results are said to be consistent. From these results it can also be known the criteria and alternatives prioritized

\section{Analysis and Discussion}

\subsection{Overview of Research Objects}

Bali is one of the thousands of islands that are part of the Unitary State of the Republic of Indonesia. Because of its unique features, Bali has become a prime destination for tourists from all over the world, who have chosen to travel to the tropics of Asia.

\subsubsection{Respondent Profile}

1) Gender of Respondents $40 \%$ of women and $60 \%$ were men taken as respondents taken in the study as

2) Age of Respondents The average age of respondents visiting Bali is $20-24$ years old at $30 \%$, age 25 29 years old at $21 \%$, and ages $30-34$ years at $19 \%$, the rest is between $40-44$ years old and between 15 - 19 years old.

3) Country of origin

The country of origin of foreign tourists visiting Bali is mostly from the United States of America 34\%, the United Kingdom 23\%, and the rest comes from various other countries.

4) Type of Work

The types of work of foreign tourists visiting Bali Island are mostly 223 students and 64 people with the teaching profession, and the rest for other professions. 
The Calling ...

5) Length of stay

Average length of stay of foreigners on Bali Island for 1 - 10 days by $38 \%$, for $11-20$ days by $36 \%$, and for $21-30$ days by $23 \%$, and only a few more than 30 days which is $3 \%$.

\subsection{Discussion of AHP Analysis}

AHP analysis is used to determine the priority factors that determine the foreign tourists on vacation to Bali. Determination of criteria is obtained from the results of studies through books on marketing and tourism literature. From the results of the study, results were obtained that in order to find out the factors that influence foreign tourists on vacation to Bali Island can be reached through seven criteria, namely: (1) Product Factors; (2) Price Factors; (3) Place Factors; (4) Promotion Factors; (5) Process Factors; (6) People Factors; (7) Physical Evidence Factors;

Like the determination of criteria, alternatives or used in this study also come from studies through books on marketing and tourism literature. From the results of these studies, an alternative can be used to find out more intensely and sharply what factors influence foreign tourists to vacation in Bali: (1) Core Product; (2) Expected Product; (3) Augmented Product; (4) Direct; (5) Indirect; (6) Advertising; (7) Instructional Material; (8) Public Relations; (9) Standardized; (10) Customized; (11) Contractors; (11) Modifiers; (12) Essential Evidence; (13) Peripheral Evidence.

If arranged in a hierarchy, two levels will be obtained, namely criteria and alternatives as shown in the following figure:

\section{Hierarchy of Tourism Marketing Mix}

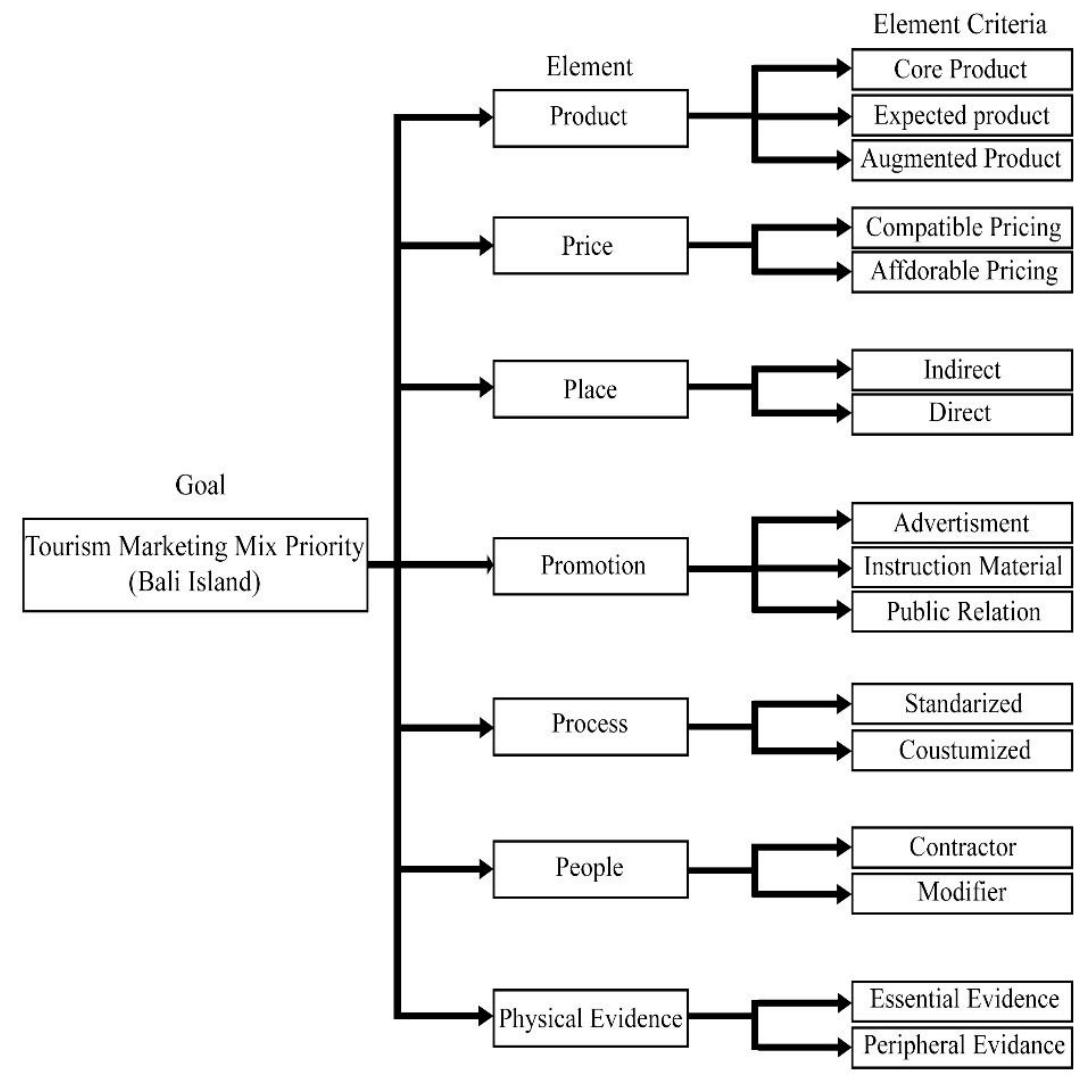


The step in determining the priority of factors affecting foreign tourists on holiday to Bali Island, an assessment is needed from respondents; in this case, the foreign tourists themselves. The analytical tool used to process it is the Expert Choice application version 11.

Stage one, analyzing the elements of all the criteria that are a priority for foreign tourists on vacation on the island of Bali

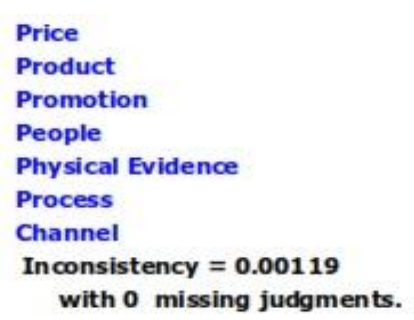

Figure 4.1. The Priority of Overall Marketing Mix Criteria Factors for Vacation Destinations in Bali

Based on AHP processing, it is known that the criteria factor that has the highest value is the price factor with a value of 0.200 . This shows that the price factor is the primary consideration for foreign tourists in carrying out tourism activities on the island of Bali. Prices are considered an element of the marketing mix that can generate profits through the income earned from the pricing. Determining the right price, both based on the level of competition and based on price compatibility with product quality, is needed to achieve the goal of increasing the number of foreign tourists.

The second position is occupied by the product criteria factor after the price criteria factor with a weight of 0.160 . As an island with the title of the Most Beautiful Island in Asia for tourism destinations according to the international travel magazine 2012, of course, there is no doubt about the tourism products offered so that it can attract so many foreign tourists on vacation to Bali. It is hoped that the more active parties involved in continuing to innovate and develop tourism products offered will attract more foreign tourists to vacation in Bali.

The promotion criteria factor occupies the third priority of the marketing mix priority towards the vacation destination to Bali Island with a weight of 0.159 . Foreign tourists consider that promotion plays an important role, which is a matter of consideration for them to vacation in Bali. The fourth priority of the marketing mix with the aim of vacationing to Bali Island is people or human resources with a weight of 0.134 .

Factors of human resources are factors that must be considered in the marketing mix, as businesses that offer services, human resources are the factors that determine the quality of the services provided by tourist attractions. Therefore, the island of Bali also needs to pay attention to the strategies of people in their marketing strategies to increase the number of foreign tourist visits.

Factors of physical evidence criteria get the fifth priority for vacationing to Bali Island with a weight of 0.123 . Physical evidence is a facility that supports the existence of a tourist destination. The more complete the facilities of a tourist destination, it will give satisfaction to visitors to the available facilities so that it is expected to make a return visit and provide useful information to relatives, friends and other communities about the superiority of tourism in Bali.

The sixth position is occupied by the criteria for the process of vacation destinations to Bali with a weight of 0.116 . The process is a factor that must be considered so that visitors feel satisfied with the process of service provided. The success of a process will also affect 
The Calling ...

the achievement of company goals or in this case, the tourism providers, namely an increase in the number of foreign tourist visits.

The lowest criterion factor is the criterion of place or distribution flow with a value of 0.107. Looking at the conditions of Bali's tourism which are closely related to the international development, of course, it is inevitable that there have been many businesses (indirect distribution) of tourist bureaus on the island of Bali that compete with each other to attract foreign tourists on vacation. As for those who still actively promote tourism products not through intermediaries or in other words, they sell them directly. Of all tourist products that are channeled both directly (direct distribution) and indirect (indirect distribution) to foreign tourists, and the increasingly advanced technology and information, it is expected that this can facilitate tourism providers to be able to continue to develop their product distribution channels in order to continue increasing the number of foreign tourist visits to Bali.

From the elaboration of the numbers above, we can conclude the factors of price or expensive prices for the main factors that are considered for tourists to determine tourist visits to the island of Bali. In other words, the price of tourism on the island of Bali is still in a competitive or cheap category to make it easier for those who are interested in vacationing.

For the place factor (channel) which is the thing which is the distribution channel where the products distributed are related, the results of the data calculation above show the distribution channel factors which have the lowest value of 0.107 . This indicates that the distribution factor is the least dominant factor from other factors as consideration for tourists in making decisions for a vacation to Bali.

Stage 2, determine alternative priorities for each criterion from product criteria to physical evidence. The results of the processing of the PPA are as follows.

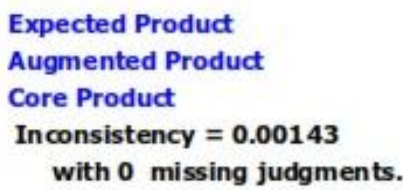

\section{Figure 4.2. Priority Elements of Product Criteria for the Purpose of Vacation to the \\ Bali Island}

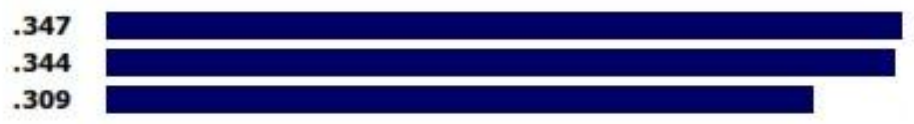

Data source: processed by the author

The results of the priority analysis of product marketing mix criteria elements in Bali tourism show that the element of expected product is the top priority compared to other product marketing mix criteria elements with a weight of 0.347 . Moreover, for the augmented product marketing mix criteria, the second priority weighs 0.344 , which is then followed by the core product marketing mix criteria as the last priority with a weight of 0.309 .

A product consists of one core circle that provides core benefits and the next four layers: core product, expected product, augmented product, and product potential. The first layer is generic if it is associated with tourism services; this product is to meet the basic needs of tourists such as relaxation, leisure, heritage, adventure, and cultural knowledge and experiences. The second layer (expected product) not only meets the needs (needs) of tourists, but also the wants (wants) and expectations (expectation) of tourists.

Then penetrate to the next layer, namely augmented product by giving added value to beyond what is expected by tourists. In essence, what is meant by augmented product is a product that exceeds the expectations of tourists to get something extra and desirable. For example, the level of service provided by staff at travel agencies or hotels that govern 
bookings and the way tour operators handle tourist complaints. All of these services are referred to as "value added" from a tourism product.

From all the elements of the product criteria if it is associated with the results of data processing on each priority level, it can be seen that the tourism conditions of Bali Island, especially when viewed in terms of tourism products, are found that there is a tendency for foreign tourists to prioritize more product than augmented product and core product. The finding indicates that even though Bali Tourism has an awe-inspiring core product as a tourist destination to be able to feel relaxation, leisure, heritage, adventure, and learn new culture knowledge with natural beauty and exoticism of the region that can attract many foreign tourists, it cannot be denied that tourists also continue to expect a unity of tourism product attributes in a reasonable condition (expected product) like a tourist destination, namely a comfortable and clean tourist spot. Similarly, at the inn, have clean rooms, bed linen, towels, other equipment such as hangers and privacy rooms

Moreover, the last is the core product. The core product itself is the previous priority for foreign tourists from all elements of the criteria for Bali tourism products. This indicates that basically, core products from Bali Island tourism itself are not taken into consideration in Bali's tourism conditions. There are several possibilities that can cause this to happen, not because of the lack of quality from core product tourism in Bali itself, but when referring to international travel magazines which release ten of the most beautiful islands in Asia for 2012, Bali Island is ranked first among the islands others followed by Phuket Island in Thailand and so on up to the last position occupied by Mindanao Island in the Philippines. This phenomenon shows that in fact there is no doubt about the quality of the core product of Bali Island itself for foreign tourists as tourist destinations, but there are several other things from the elements of product criteria which are the primary considerations for them, namely elements of expected products as mentioned above.

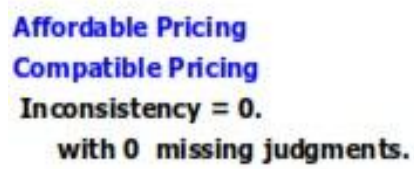

Figure 4.3. Priority Price Criteria Elements for Vacation Destinations to Bali
.535

.465

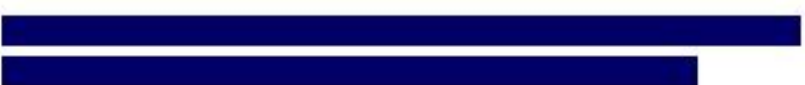

(1) 
The Calling ...

competitive and relatively inexpensive tourist prices can be created and can continue to increase foreign tourist visits to Bali.
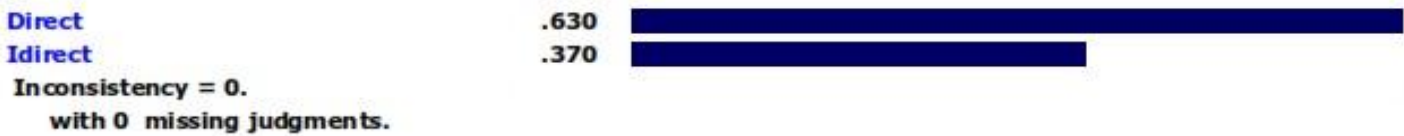

Figure 4.4. Priority Place Criteria Elements for Objectives Vacation to the Bali Island Data source: processed by the author

The results of the priority analysis of place marketing mix criteria elements in Bali tourism show that the element of direct distribution is a top priority compared to other elements with a weight of 0.630 . Moreover, for the direct distribution marketing criteria element gets the second priority with a weight of 0.370 .

To understand tourism marketing, of course, in-depth knowledge is needed about the characteristics of the distribution of tourism products themselves. Tourism products that are rich in-service nuances have characteristics, namely in the absence of physical distribution in their business. Tourism product providers can provide their products directly to tourists (direct distribution) or through travel trade services both online and offline.

From the findings above, it can be concluded that many of the foreign tourists are reluctant to go on vacation to Bali Island through travel agents, they are more likely to make purchases directly from the purchase of round-trip aeroplane tickets, to tourism activities in Bali to hotel bookings.
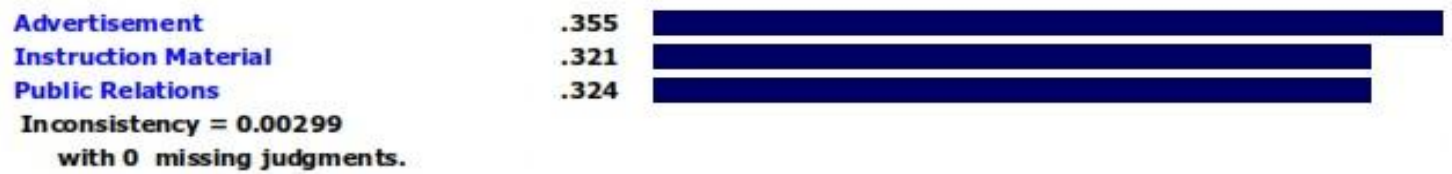

Figure 4.5. Priority Promotion Criteria Elements for Objectives Vacation to the island of Bali

Data source: processed by the author

The results of the priority analysis of the marketing process mix criteria elements in Bali tourism show that customized elements are the top priority compared to other elements with a weight of 0.667 . And for standardized marketing mix criteria elements get the second priority with a weight of 0.333 .

From the findings above, it shows that many foreign tourists prioritize processes that can be tailored to the needs and desires of each of them, from departure flights, activities at the hotel, and other tourism activities compared to standardized processes. This finding is true that based on the theory of Sarker, et al. (2012) regarding the tourism process, there is a tendency that foreign tourists will feel dissatisfied if the service they receive is not in accordance with their needs or in other words a service process that cannot be customized according to the needs of tourists.

Customized

Standardized

Inconsistency $=0$.

.333

with 0 missing judgments.

Figure 4.6. Priority Criteria Process to go on vacation to the Bali Island Data source: processed by the author 
The Calling ...

architecture, the surrounding environment, landscape and interior design, causing a high priority of tourists for the element of essential evidence compared to peripheral evidence.

\section{CONCLUSIONS AND SUGGESTIONS}

\subsection{Conclusion}

Following the phenomenon described in the formulation of the problem, which is about the marketing mix factors, which is a priority for foreign tourists regarding Bali Island tourism, the findings from the results of this study can also be concluded with the following explanation:

1. Overall, the marketing mix criteria that should be prioritized by tourism service providers and related regulators in order to increase the number of foreign tourists are the price marketing mix criteria, because based on the calculation results of the expert choice version 11 this criterion gets the highest score of 0.200 . The marketing mix criteria that get the lowest value are places or product distribution channels with a score of 0.107 .

2. Criteria element of the price marketing mix that gets the highest value is affordable pricing with a value of 0.535 , while the criteria element that gets the lowest value is compatible pricing. Policies regarding efficient tourism management to reduce costs that must be incurred by foreign tourists and of course, can increase foreign tourist visits.

3. Based on the criteria for the marketing mix of a place or tourism product distribution channel, the direct distribution criteria element gets the highest value of 0.630 , while the criteria element that gets the lowest value is the indirect distribution with a value of 0.370 . With the increasingly varied services and the increasing level of trust given, it is expected to increase tourist visits through tourism bureaus which will be able to provide benefits to the industry.

4. Criteria element of the product marketing mix that gets the highest value is expected product with a value of 0.347 , then followed by an augmented product with a value of 0.344 and the last one occupied by core product criteria with a value of 0.309 . Not only in tourist attractions, other supporting facilities must be arranged well and cleanly.

5. Based on the promotion marketing mix criteria, the element of the advertisement criteria gets the highest value of 0.355 , after which the instructional material is followed by the acquisition of 0.321 , while the criteria element that receives the lowest score is public relations with a value of 0.324 . Thus, the policy that should be a priority for tourism providers in terms of promotion is the advertisement to continue to attract the attention of foreign tourists to visit the Bali Island.

6. The criteria element of the human resource marketing mix that gets the highest score is the modifier with a value of 0.518 , while the criteria element that gets the lowest score is contractors 0.482 , by conducting training or seminars on service excellence to improve excellent service to tourists.

7. Based on the marketing evidence mix criteria, the essential evidence criteria element gets the highest value of 0.570 , after which peripheral evidence is followed as the last position with a value of 0.430 . For the government, it's good to hold various programs that support the sustainability of tourist destinations on the island of Bali.

8. Criteria element of the marketing mix the process that gets the highest score is customized with a value of 0.667 , while the criteria element which gets the lowest score is standardized 0.333 . So from that the policy that should be carried out by tourism providers is about the development and innovation of their services that can 
be adjusted to the wishes of tourists through development to increase foreign tourist visits to the Bali Island.

9. Overall, from the priority sequence of 16 elements of the tourism marketing mix criteria, the policy that should be the priority of tourism service providers and the government is about efficient tourism management because this alternative gets the highest value compared to other alternatives with a value of 0.095 . The elements that get the lowest value are standardized criteria elements with a value of 0.028 .

\section{Suggestions}

Based on the discussion above, some suggestions can be made, namely:

1. In order to be more precise in explaining and completing the results of the analysis for the purpose of this study, the researcher suggests strengthening in the discussion of the concept of this research, both in the scope of theory (additions), reference to previous research, research models to the calculation and analysis of research. As for those related to strengthening research variables, the focus of research analysis includes the product variable and physical evidence. In this case the researcher tries to attach the theory and the example of the revised questionnaire regarding the discussion of product and physical evidence variables in the appendix with the revised title of the questionnaire.

2. Important (alternative) variables in core products need additional discussion. For example, in augmented product issues regarding the method of payment and government regulation are important in the world of tourism, which will affect tourists deciding to take a vacation somewhere. Whether in tourist destinations that tourists go to there are conveniences (alternatives) in payment methods such as debit and credit card networks (Cirrus, Alto, Visa, MasterCard, etc.).

\section{References}

An Emperical Study of The Impact of Marketing Mix Factors on Tourists Satisfaction: A Case of Selected Three States In India." n.d.: 7.

Armstrong, Philip Kotler and Gary. Principles of Marketing. Fourteenth . Pearson, 2012.

Bali, Dinas Pariwisata Pemerintah Provinsi. n.d. Fast Fact About Bali. Accessed March 2013. http://www.tourism.baliprov.go.id/.

Beneke, Justin. 2004. (accessed 3 4, 2013).

Bonera, Michelle. "The Vacation Decision Making Process: Tourism in The Garda Lake." 8th Global Confrence on Business and Economics, October 2008: 19.

Christopher H. Lovelock, Lauren K. Wright. Manajemen Pemasaran Jasa. Prentice Hall, 2007.

Department of Investment Services, Ministry of Economic Affairs . "Meeting, Incentive, Convention, and Exhibition (MICE) Industry: Analysis \& Investment Opportunities ." n.d.: 25.

Dimanche, Frederic. "Understanding Tourist Motivations and Their Quest for Experiences." Nova Scotia Tourism Research Forum, May 2010: 29.

Ebert, Ricky W Griffin and Ronald J. 2009. Business Essentials. Pearson Education.

Gajić, Jelena. "Importance of Marketing Mix in Higher Education Institutions." Singidunum journal, 2012: 13.

Hamdani, Rambat Lupiyoadi - A. Manajemen Pemasaran Jasa. 2. Jakarta Selatan, Jakarta Selatan: Salemba Empat, 2008.

Informasi Tempat Wisata. 2012. http://www.tempat-wisata.info/2012/12/10-pulau-terbaik-diasia-tahun-2012.html (accessed Maret 4, 2013). 
The Calling ...

Kanuk, Leon G. Schiffman and Lazar. Consumer Behavior. Tenth . Pearson, 2010.

Lita, Ratni Prima. "Pengaruh Implementasi Bauran Pemasaran Jasa Terhadap Proses Keputusan Wisatawan Mengunjungi Objek Wisata dl Kota Padang." 2 (JuliDesember 2010): 9.

Livkunupakan, Nirunkiat. "One Tambon One Product Empirical Evidence and Market Orientation from Five Southern Border Provinces of Thailand ." 1 (2007): 10.

Logan, Gabi. USA Today. 2012. http://traveltips.usatoday.com/sustainable-tourism-bali53894.html (accessed March 3, 2013).

M.Syamsul Ma'Arif, Hendri Tanjung. Teknik-Teknik Kuantitatif untuk Manajemen. Grasindo Gramedia Widiasarana Indonesia, 2003.

Mohammad Amzad Hossain Sarker, Dr. Wang Aimin, and Sumayya Begum. "Investigating the Impact of Marketing Mix Elements on Tourists Satisfaction: An Empirical Study on East Lake." European Journal of Business and Management 04 (2012): 11.

Özer, Özgür. "The Role of Marketing Mix Components in Destination Choices of Visitors and the Case of Dalyan." Journal of Business Research-Türk, n.d.: 182.

"Pengaruh Bauran Pemasaran Jasa Terhadap Loyalitas Nasabah Pada PT. Bank Rakyat Indonesia (PERSERO) Tbk, Cabang Achmad Yani Makasar." Fitriani Dayasari Hasan, 2012: 112.

Purnamasari, Yulia Endah Sukma. "Analisis Pengaruh Bauran Pemasaran Terhadap Keputusan Wisata Asing Berlibur di Kota Semarang." 2011: 72.

Rattanakitrungrueang, Sudara. "A Study of Marketing Mix Factors Influencing Tourist's Tourism Decison To Travel To Sukhothai." June 2007: 110.

Rezky Purna Satit, Huam Hon Tat, Amran Rasli, Thoo Ai Chin, Inda Sukati. "The Relationship Between Marketing Mix And Customer Decision-Making Over Travel Agents: An Empirical Study." International Journal of Academic Research in Business and Social Sciences 2 (june 2012): 9.

Simm, Carole. USA Today. 2012. http://traveltips.usatoday.com/sustainable-tourism-bali63336.html (accessed March 3, 2013).

Somantri, Lili. "Keunggulan Bali Sebagai Daerah Tujuan Wisata Andalan Indonesia." n.d.: 10.

Stynes, Daniel J. "Economic Impacts of Tourism." n.d.: 19.

Ujiani, Dwi Pangastuti. "Analisis Peranan Jasa Pariwisata dan Sektor Pendukungnya Dalam Perekonomian Propinsi Daerah Istimewa Yogyakarta." 2006: 124.

Wahab, Salah. Pemasaran Pariwisata. Jakarta: PT.Pradnya Paramita, 1997.

World Economic Forum. "The ASEAN Travel \& Tourism Competitiveness Report 2012 ; Fostering Prosperity and Regional Integration Through Travel and Tourism." Insight Report, 2012, 45. asean

, Oka A. Pemasaran Pariwisata. Bandung: Angkasa, 1980.

Zeithaml, Valarie A. Services Marketing. Fifth. Mcgraw-Hill, 2009.

http://www.travelandleisure.com/worldbest/2012/islands (accessed March 3, 2013).

http://www.rappler.com/life-and-style-/8275-boracay-beats-santorini (accessed March 3, 2013). 